\title{
Relationship between Body Weight Performance and Plasma Thyroid Hormones in Broiler Hens
}

\author{
Rabia M. Elwahesh ${ }^{1}$, Khalid M. Ben-Elhaj2, Marwan M. Draid ${ }^{3 *}$ \\ 1Department of Biology, Faculty of science / agelat, University of Zawia, 16418, Zawia, Libya. \\ 2Department of Physiology, Biochemistry \& Animal nutrition, \\ Faculty of Veterinary Medicine, University of Tripoli, 13662, Tripoli, Libya. \\ 3Department of Pharmacology, Toxicology \& forensic Medicine, \\ Faculty of Veterinary Medicine, University of Tripoli, 13662, Tripoli, Libya.
}

\begin{abstract}
Aims: To investigate the effect of thyroid hormones Thyroxine (T4) and Triiodothronine (T3) on bodyweight performance in broiler hens.

Methodology: The hens were kept in a controlled environment of $50-60 \%$ humidity at $31^{\circ} \mathrm{C}$ in first two weeks than temperature been decreased to $24^{\circ} \mathrm{C}$ with $24 \mathrm{hr}$ light cycle per day, and were treated gently. Water and feed were provided ad libitum for the all hens. The body weight of the birds detected at the day $2 \mathrm{nd}, 4$ th, $6^{\text {th }}$ and 8 th week of the experimental period and blood sample detected at the day 14th,28th,42th and 56th day of the experimental period. The data were analyzed by the analysis of variance technique in completely randomized design, while the differences between means were tested by Duncan New Multiple Range Test as per SAS.

Results: It was noted that there is a highly significant effect of age, at the level $(P \leq 0.01)$ on the characteristics of each of the concentration of the hormone T3 and T4 hormone levels and body weight. This study showed that there is a difference in the average concentration of "T4 \& T3" for meat birds of different ages. The correlation coefficient manner, "Pearson" between the different qualities of the birds of the meat where it was noted there is a strong inverse relationship between "T4 \& T3".
\end{abstract}

\section{INTRODUCTION}

The thyroid is an endocrine organ and thyroid hormones have multiple effects on vertebrate metabolism and development and the avian gland is similar in many respects to that of mammalian. It is well established that thyroid hormones regulate the energy metabolism of most tissues including liver, kidney, heart, skeletal muscles and brain. ${ }^{1}$ In chickens, the plasma levels of thyroid hormones are changed with ambient temperature, age, feeding status and pathophysiologic status. ${ }^{2-5}$

In birds as in other vertebrates product hormones are both thyroxine (tetra-iodothyronine or T4) and tri-iodothyronine (T3) and found been extensively investigated in human, animal. However in chickens, there is limited information about the association of thyroid hormones blood levels with growth performance in broiler chicken. In various vertebrates, alterations in the quantity and quality of ingested food influence thyroid function. ${ }^{6}$ Many studies
Conclusion: We conclude that changes in the concentration of thyroid hormones "T4 \& T3" follows the output intensity during period of broiler hens life and body weight.

Keywords: Broilers hens, Thyroxine, Triiodothronine, Bodyweight performance.

\begin{tabular}{|c|c|}
\hline \multicolumn{2}{|l|}{${ }^{*}$ Correspondence to: } \\
\hline \multicolumn{2}{|c|}{$\begin{array}{l}\text { Dr. Marwan M. Draid } \\
\text { Associate professor } \\
\text { Department of Pharmacology, } \\
\text { Toxicology and Forensic Medicine, } \\
\text { Faculty of Veterinary Medicine, } \\
\text { University of Tripoli, 13662, Tripoli, Libya. }\end{array}$} \\
\hline \multicolumn{2}{|c|}{ Article History: } \\
\hline \multicolumn{2}{|c|}{ Received: 20-10-2016, Revised: 03-11-2016, Accepted: 22-11-2016 } \\
\hline \multicolumn{2}{|c|}{ Access this article online } \\
\hline $\begin{array}{l}\text { Website: } \\
\text { www.ijmrp.com }\end{array}$ & 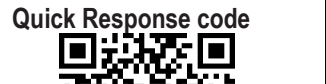 \\
\hline $\begin{array}{l}\text { DOI: } \\
\text { 10.21276/ijmrp.2016.2.6.019 }\end{array}$ & 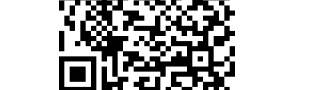 \\
\hline
\end{tabular}

demonstrated that the thyroid system is especially sensitive to carbohydrate content in diets. ${ }^{7-9}$ Glucose in diet may stimulate the secretion of thyroid hormones, ${ }^{10,11}$ especially $\mathrm{T} 4$, or may act to enhance $\mathrm{T} 4$ deiodination peripherally. ${ }^{12}$

Alternatively, other nutritional components of diet, possibly protein, may be involved in the regulation of thyroid function. Lipid on the other hand, did not appear to modify thyroid function in rainbow trout under isocaloric conditions. ${ }^{13}$

The greater parts of hormones are secreted as T4, which by the process of deiodination may revert back to reversible T3 (rT3). ${ }^{14}$ This process takes place in the peripheral circulation. Secreted hormones circulate almost entirely bound to proteins. Since avian blood plasma does not contain a specific binding globulin, as does mammalian blood, ${ }^{15}$ T3 and T4 are almost entirely bound to plasma prealbumins and albumins. ${ }^{16}$ 
Shellbarger found almost identical effects of T3 and T4 in birds, which is not the case in mammals. ${ }^{17}$ Later investigations by Bobek showed that $\mathrm{T} 3$ is the main thyroid hormone regulating oxygen consumption, particularly in young chickens. ${ }^{18}$ Klandorf and his group researcher confirmed that T3 is, in chickens, a metabolically more active substance than T4. ${ }^{19}$ The concentration of thyroid hormones circulating in chicken blood plasma was found to be around $1.2 \mu / 100 \mathrm{ml},{ }^{20}$ showing daily variations due to an extremely short half-life and showing $\mathrm{T} 3$ to $\mathrm{T} 4$ ratio to be $60: 40$, in favour of T4. ${ }^{21}$

According to collected data from the literature there is no doubt about the great involvement of thyroid hormones between each other in poultry production processes. Beside there are no previous studies investigating the relationship between the level of plasma thyroid hormones and slaughter-weight in broiler chickens during two months life cycle under nutrient high calorie diets intake. Therefore, the present study was conducted to compare the growth performance and it relationship with thyroids hormone blood concentration in different life stages in broiler chickens.

\section{MATERIALS AND METHODS}

This study was approval by University of Zawia ethics review committee. Forty male broiler hens (Cobb 500 breed) were obtained from chicken farm in Jmail town west of Zawia city, Libya, and housed in the same farm. The hens were kept in a controlled environment of $50-60 \%$ humidity at $31^{\circ} \mathrm{C}$ in first two weeks than temperature been decreased to $24{ }^{\circ} \mathrm{C}$ with $24 \mathrm{hr}$ light cycle per day, and were treated gently. Chickens were fed up during the first 28 days of age with a commercial starter diet (protein 22.45\%) and from day 28 until 35 the fattening period with a commercial grower diet (protein 20.48\%) and from 35 to final of experiments with a commercial grower diet (protein 18.54\%). The content of diets shows in (Table 1). The broiler hens were randomly distributed into four groups, each with ten birds, and those four groups were then randomly assigned to each experimental group as defined below (Table 2). Water and feed were provided ad libitum for the all hens. In our experimentation, no clinical symptoms of disease or abnormal mortalities were observed.

Data collected include body weight at 2nd, 4th, 6th and 8th week of age. Also, data were collected on body weight gain, processed ratio and mortality (if any) up to 8th week when the experiment was terminated.

Processed ratio $=($ Carcase weight $(\mathrm{g}) /$ Body weight $(\mathrm{G})) \times 100$

There was no birds mortality during the experimental period.

Samples were also taken at the end of each two weeks of the experimental period $(14,28,42$, and 56 d) each time ten birds. Blood for analysis was collected from the jugular vein and centrifuged at $3,000 \mathrm{rpm}$ for $10 \mathrm{~min}$ by Hettich universal centrifuge, serum collection plastic tubes (additive clot activator and silicone coated interior, $10.0 \mathrm{ml}$ volume) were used, and these tubes were supplied from BD Vacutainer $囚$. The resultant serum was collected and stored at $-20^{\circ} \mathrm{C}$ until analyzed.

Enzyme-Linked Immunosorbent Assay (ELISA) was used to determine plasma hormone concentrations purchased from biocheck, Inc. Using Roche Diagnostics Elecsys 2010 Immunoassay System is a fully automated, with 0.4 microgram/decilitre sensitivity range.

\section{Statistical Analysis}

The data were analyzed by the analysis of variance technique in completely randomized design, while the differences between means were tested by Duncan New Multiple Range Test as per SAS. ${ }^{22}$ Comparisons were considered significant when $p$ values were less than 0.05 .

The statistical model used was:

$$
\begin{aligned}
& Y_{i j}=\mu+A e_{i}+\varepsilon_{i j} \\
& Y_{i j}=\text { observation on (Body weight, Carcase weight) } \\
& \mu=\text { common mean } \\
& \text { Age }_{i}=\text { Age }(i=2,4,6,8) \\
& \varepsilon_{i j}=\text { error term }
\end{aligned}
$$

Table 1: Composition of three diets.

\begin{tabular}{lccc}
\hline Composition (\%) & $\begin{array}{c}\text { Starter feed } \\
\text { (Protein 22.45\%) }\end{array}$ & $\begin{array}{c}\text { Grower 1 feed } \\
\text { (Protein 20.48\%) }\end{array}$ & $\begin{array}{c}\text { Grower 2 feed } \\
\text { (Protein 18.54\%) }\end{array}$ \\
\hline Maize & 43 & 53 & 55 \\
Soya meals & 34 & 35 & 36 \\
Milling issues & 20 & 10 & 8 \\
Limestone & 1 & 0.24 & 0.09 \\
Phosphate & 0.41 & 0.39 & 0.35 \\
Mineral complex vitamins & 1.59 & 1.37 & 0.56 \\
Metabolizable energy (Kcal/Kg of diet) & 3200 & 3200 & 3214 \\
\hline
\end{tabular}

Table 2: Body weights (BW), T3, T4, T3/T4 (mean \pm SEM) in the four groups of ages ( $n=10$ for each age).

\begin{tabular}{lcccc}
\hline & 2 weeks & 4 weeks & 6 weeks & 8 weeks \\
\hline BW $(\mathbf{g})$ & $241 \pm 16.8^{\mathrm{d}}$ & $1420 \pm 51.2^{\mathrm{c}}$ & $2140 \pm 37.1^{\mathrm{b}}$ & $2740 \pm 56.2^{\mathrm{a}}$ \\
Carcass $(\mathbf{g})$ & $140 \pm 16.3^{\mathrm{d}}$ & $750 \pm 45.3^{\mathrm{c}}$ & $1440 \pm 22.1^{\mathrm{b}}$ & $1780 \pm 55.4^{\mathrm{a}}$ \\
Processed ratios\% & $56.5 \pm 2.6^{\mathrm{b}}$ & $52.8 \pm 2.4^{\mathrm{b}}$ & $67.4 \pm 1.2^{\mathrm{a}}$ & $64.9^{\mathrm{b}} \pm 1.4^{\mathrm{a}}$ \\
T3 (nmol/l) & $4.8 \pm 0.3^{\mathrm{a}}$ & $3.5 \pm 0.5^{\mathrm{b}}$ & $1.8^{\mathrm{a}} \pm 0.2^{\mathrm{c}}$ & $4.6^{\mathrm{a}} \pm 0.3^{\mathrm{a}}$ \\
T4 (nmol/l) & $12.4 \pm 1.3^{\mathrm{bc}}$ & $13.8 \pm 0.9^{\mathrm{b}}$ & $20.5 \pm 0.9^{\mathrm{a}}$ & $10.1 \pm 0.5^{\mathrm{b}}$ \\
T3/T4 ratio & $0.4 \pm 0.1^{\mathrm{a}}$ & $0.3 \pm 0.1^{\mathrm{b}}$ & $0.1 \pm 0.1^{\mathrm{c}}$ & $0.5^{\mathrm{b}} \pm 0.1^{\mathrm{a}}$ \\
\hline
\end{tabular}

- a,b,c, means in the rows with different letters differ significantly $\mathrm{P}<0.05$.

- T3 = Triiodothyronine; T4 = Thyroxine 
Rabia M. Elwahesh et al. Body Weight Performance and Plasma Thyroid Hormones in Broiler Hens

Table 3: T3 and T4 concentration, and mean of different ages for broilers hens

\begin{tabular}{lcccc}
\hline & 2 weeks & 4 weeks & 6 weeks & 8 weeks \\
\hline $\mathrm{T} 3(\mathrm{nmol} / /)^{1}$ & $3.2 \sim 6$ & $1.3 \sim 6$ & $1.1 \sim 2.6$ & $3.1 \sim 5.7$ \\
$\mathrm{~T} 3(\mathrm{nmol} / \mathrm{l})^{2}$ & $4.8 \pm 0.3$ & $3.5 \pm 0.5$ & $1.8 \pm 0.2$ & $4.6 \pm 0.3$ \\
$\mathrm{~T} 4(\mathrm{nmol} / \mathrm{l}){ }^{1}$ & $7.6 \sim 20.3$ & $9.0 \sim 18.9$ & $15.1 \sim 26.6$ & $8.1 \sim 13.2$ \\
$\mathrm{T4}(\mathrm{nmol} / \mathrm{l})^{2}$ & $12.4 \pm 1.3$ & $13.8 \pm 0.9$ & $20.5 \pm 0.9$ & $10.1 \pm 0.5$ \\
\hline
\end{tabular}

${ }^{1}$ Hormone (Low concentration $\sim$ High concentration) recorded.

2 mean \pm SD

Table 4: Pearson's correlation coefficient between hormones concentration and body, carcase weight.

\begin{tabular}{lcccc}
\hline & T4 $(\mathrm{nmol} / \mathrm{l})$ & BW $(\mathrm{g})$ & Carcase $(\mathrm{g})$ & Processed ratios $\%$ \\
\hline T3 $(\mathrm{nmol} / \mathrm{l})$ & $-0.7^{* *}$ & -0.3 & $-0.3^{*}$ & $-0.3^{*}$ \\
BW $(\mathrm{g})$ & 0.1 & - & $0.9^{* *}$ & $0.5^{\star *}$ \\
Carcase $(\mathrm{g})$ & 0.2 & $0.9^{* *}$ & - & $0.6^{* *}$ \\
Processed ratios $\%$ & $0.5^{*}$ & $0.5^{* *}$ & $0.6^{* *}$ & - \\
\hline
\end{tabular}

Fig 1: Relationship between means of body, carcase weight with mean of $\mathrm{T} 3, \mathrm{~T} 4$ concentration during experiment.
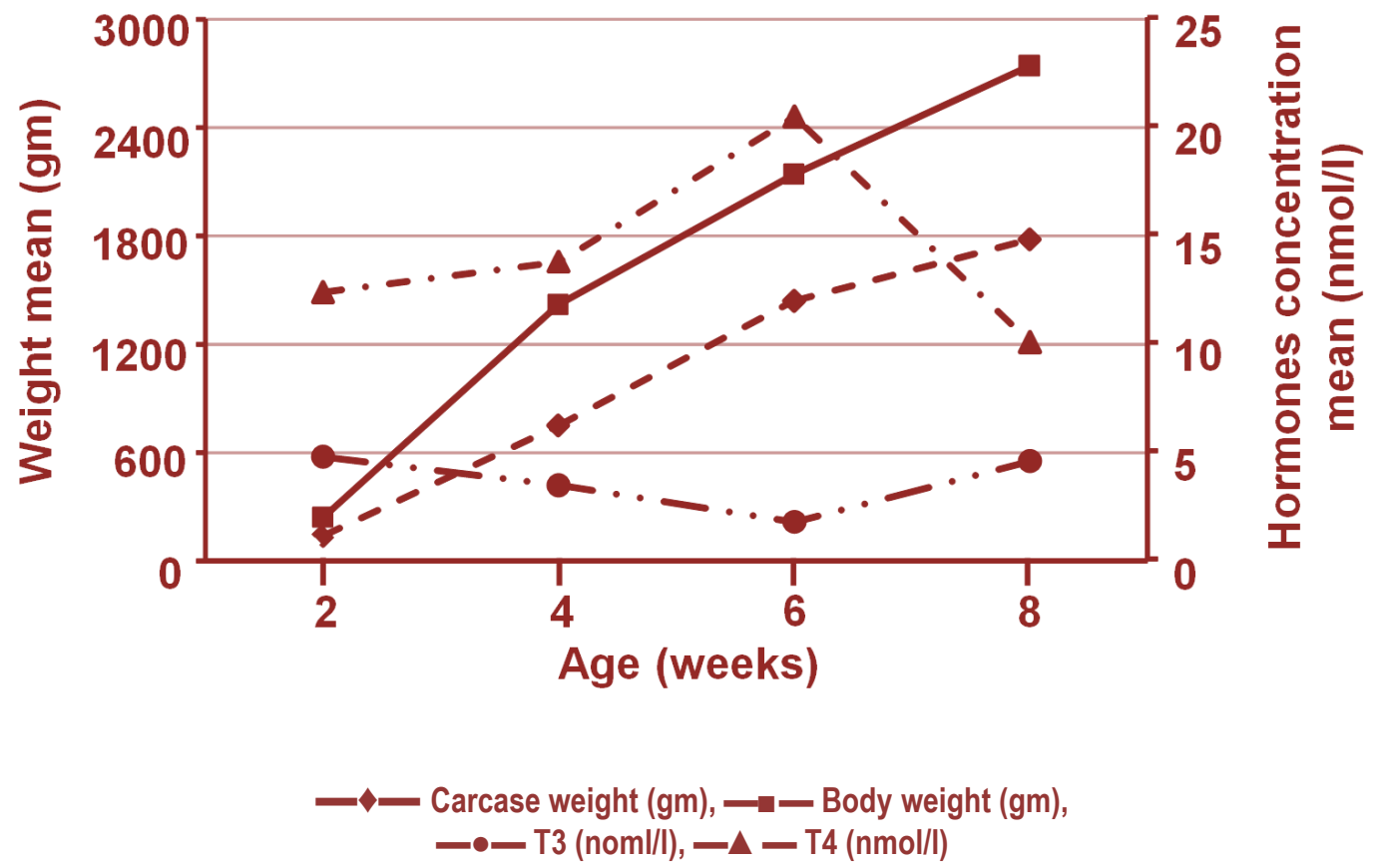

\section{RESULTS}

Table (2) and figure (1) shows different productive qualities of meat birds of different ages. It was noted that there is a highly significant effect of age, at the level $(P \leq 0.01)$ on the characteristics of each of the concentration of the hormone $\mathrm{T} 3$ and T4 hormone levels and body weight, "live weight of the bird" and the net weight of the meat, as well as dressing percentage. Comparing the averages values by "Duncan". There were no significant differences at the level of $(P \leq 0.05)$ between the average concentration of the hormone T3 at the age of 2 and 8 weeks, there mean were 4.8 and $4.6 \mathrm{nmol} / \mathrm{L}$, respectively. On the other hand, there were significant differences between the former intermediate and the average concentration of the hormone $\mathrm{T} 3$ at the age of 4 and 6 weeks and were 3.5 and $1.8 \mathrm{nmol} / \mathrm{L}$, respectively. On the other hand, the ratio of net meat at the age of 6 weeks is the highest, reaching $67.4 \%$ and at this age it was observed that the concentration of T3 hormone has reached less than his average concentration of $1.8 \mathrm{nmol} / \mathrm{L}$ as shown in table 2 .
The results of this study showed that there is a difference in the average concentration of thyroid hormones "T4 \& T3" for meat birds of different ages, as shown in (Table 3 ) and explained that these results hormone T4 concentration was higher than the concentration of the hormone $\mathrm{T} 3$ for all ages. The results of this study showed that the hormone T4 concentration increases with the age of the bird, and that was evident in the first three ages of the study (2.4 and 6 weeks) with an average concentration of this hormone to the maximum concentration to him at the age of 6 weeks with an average $0.9 \pm 20.5 \mathrm{nmol} / \mathrm{L}$ and the concentration of this hormone fell at the ge of 8 weeks to reach a concentration of less than an average of $0.5 \pm 10.1 \mathrm{nmol} / \mathrm{L}$. These study results also showed that the hormone concentration of T3 birds meat at least the progress of the age of the bird and it was so obvious in the first three ages of the study (2.4 and 6 weeks), where he arrived to a lower his concentration at the age of 6 weeks, an average of $0.2 \pm 1.8 \mathrm{nmol} / /$ and then It rose at the age of 8 weeks to up to $0.3 \pm 4.6 \mathrm{nmol} / /$. 
Table 3 shows the correlation coefficient manner, "Pearson" between the different qualities of the birds of the meat where it was noted there is a strong inverse relationship between hormonal thyroid "T4 \& T3" concentration for all ages studied for chicken meat, the greater the one Say the other and vice versa, and the correlation coefficient $(r=-0.69)$, and this was the relationship direct correlation between the hormone T4 and the live weight of the body and the weight of net meat, as well as dressing percentage, ie, the greater one another has increased, and vice versa, and came correlation "r" coefficients $(0.10,0.15$ and 0.49$)$, respectively. While came this relationship is inverse between hormone T3 and the live weight of the body and the weight of net meat, as well as dressing percentage of any greater the one Say the other and vice versa. The link "r transactions" (- 0.3, - 0.3 and -0.3 ) respectively.

\section{DISCUSSION}

The relationship between performance of strain broiler hens and metabolic disorders under different feed restriction and environment control already been presented in several previous research. ${ }^{23-25}$ Previous researcher published that only free hormones are responsible for different biological activity of thyroid hormones and available to tissues. ${ }^{26}$ Our results after finishing the experiment evident that the increase in the bird's weight linked to a lack of the Plasma Free Thyroxine (T3) levels this is consistent with the results of the study carried out by several researcher findings that the rate of increase in body weight and rapid growth rate of chicken meat is linked to a lack of the hormone T3 concentration. ${ }^{27-29}$

The results of this study showed that there is a difference in the average concentration of thyroid hormones "T4 \& T3" for meat birds of different ages, as shown in Table 2 and explained that these results hormone T4 concentration in plasma was higher than the concentration of the hormone T3. For all ages studied. Similar to our finding been reported that the excretion mainstream of the thyroid gland it is a hormone triiodothronine (T4) hormone, but in fact does not mean that the hormone $\mathrm{T} 4$ remain in high level, it turns into the cells to the hormone T3, which is the most active of the hormone T4. ${ }^{30-32}$ In 1-2- week-old chickens there is a rapid increase of T3 in blood plasma and a successive increase in oxygen consumption. Maximal T3 concentration was achieved at the 2nd day after hatching. The T4 concentration also increased simultaneously, but this increase was expressed more gradually and with lesser intensity. ${ }^{18}$

Hormone T4 concentration increases with the age of the bird, and that was recorded in the first three ages of our study, experiment conducted at Mazandaran University in Iran this experiment reported that concentration of the hormone $\mathrm{T} 4$ increases with the age of the bird, reaching the maximum concentration of him at the age of 6 weeks with an average $0.8 \pm 16.7 \mathrm{ng} / \mathrm{ml}$, while the concentration of this hormone fell at the age of 7 weeks, reaching an average of $0.8 \pm 16.5 \mathrm{nmol} / / .^{33}$

Finally our result consistent with the results of other experiment carried out by the researcher Stojevic and others in Zagreb University, Zagreb in Croatia in 2000, where the experiment was conducted on meat Omar Chicken (4.5 and 6 weeks) where it was noted that the hormone T4 concentration increases with age bird, reaching its highest concentration at 6 weeks of age with an average $1.55 \pm 31.0 \mathrm{nmol} / / .{ }^{4}$ Considering the metabolic role of the thyroid hormones in the organism, these results should be expected. The changes in relative growth rate and free thyroxine concentrations support the classical observations that thyroid hormones are necessary for growth. It is generally thought that T4 is the predominant thyroid hormone in circulation, but it has little inherent biological activity, the more metabolically active thyroid hormone is $\mathrm{T} 3 .{ }^{34}$

\section{CONCLUSION}

According to the results of this study we conclude that changes in the concentration of thyroid hormones follows the output intensity during this period of broiler hens life, and a rise in the concentration of the hormone T4 in the blood plasma is associated with an increased production of the thyroid gland during this period of broiler hens life, while the decline in T3 hormone concentration in the blood plasma of birds during this period it is associated with an increased and demand of this hormone for growth during same period, and due to its use in different metabolism, especially in the field of bio-oxidative metabolism.

\section{ETHICAL APPROVAL}

The study was approved by the Institutional Animal Ethics Committee.

\section{REFERENCES}

1. Eshkhatkhah B, Sadaghian M, Eshkhatkhah S, Pourabi S, Najafian K. Relationship between the blood thyroid hormones and lipid profile in Moghani sheep, influence of age and sex. Comp. Clin. Path. 2010;19:15-20.

2. Decuypere E, Kühn ER. Alterations in thyroid hormone physiology induced by temperature and feeding in newly hatched chickens. Acta Physiol. Pol. 1988;39:380-391.

3. Lin H., Du R, Gu XH, Li FC, Zhang ZY. A study on the plasma biochemical indices of heat-stressed broilers. Asian-Aust. J. Anim. Sci. 2000;13:1210-1218.

4. Stojevic Z, Milinkovic-Tur S, Curcija K. Changes in thyroid hormones concentrations in chicken blood plasma during fattening. Vet. Arhiv. 2000;70:31-37.

5. Luger D, Shinder D, Yahav S. Hyper- or hypothyroidism: its association with the development of ascites syndrome in fastgrowing chickens. Gen. Comp. Endocrinol. 2002;127:293-299.

6 . Eales JG. The influence of nutritional state on thyroid function in various vertebrates. Amer. Zool. 1988;28:351-362.

7. Harvey S, Klandorf $H$, Phillips JG. Effect of food or water deprivation on circulating levels of pituitary, thyroid and adrenal hormones and on glucose and electrolyte concentrations in domestic ducks (Anas platyrhynchos). J Zool (London), 1981;194:341-361.

8. Young, RA, Braverman LE, Rajatanavin R (1982). Low proteinhigh carbohydrate diet induces alterations in the serum thyroninebinding proteins in the rat. Endocrinol. 1982;110:1607-1612.

9. Danforth EJr. Effects of fasting and altered nutrition in thyroid hormone metabolism in man. In "Thyroid Hormone metabolism" Ed by G Heneman, Dekker, New York pp 335-358, 1986.

10. Himick BA, Eales JG. The acute effects of food and glucose challenge on plasma thyroxine and triiodothyronine levels in previously starved rainbow trout (Oncorhynchus mykiss). Gen. Comp. Endocrinol. 1990;78:34-41. 
11. Hughes J, Burger AG, Pekary AE, Hershman JM. Rapid alterations of serum thyrotropin, triiodothyronine and reverse triiodothyronine levels to short-term starvation and refeeding. Acta Endocrinol. 1984;105:194-199.

12. Decuypere E, Kühn ER. Effect of fasting and feeding time on circadian rhythms of serum thyroid hormone concentrations, glucose, liver monodeiodinase activity and rectal temperature in growing chickens. Domest. Anim. Endocrinol. 1984;1:251-262.

13. Eales JG, Higgs DA, Uin LM et al. Influence of dietary lipid and carbohydrate levels and chronic 3,5,3'triiodothyronine treatment on thyroid function in immature rainbow trout, Oncorhynchus mykiss. Gen. Comp. Endocrinol. 1990; 80:146-154.

14. Klandorf $H$, Sharp PJ, Duncan IJH. Variations in levels of plasma thyroxine and triiodothironine in juvenile female chickens during 24- and 16- hr lighting cycles. Gen. comp. Endocrinol. 1978;36:238-243.

15. Farer LS, Robbins J, Blumberg BS, Rall JE. Thyroxine-serum protein complexes in various animals. Endocrinol. 1961;70:686696.

16. Heniniger RW, Newcomer WS. Plasma protein binding, halflife, and erythrocyte uptake of thyroxine and triiodothyronine in chickens. Exp. Biol. Med. 1964;116:624-628.

17. Shellbarger CJ. A comparison of triiodothyronine and thyroxine in the chick goiter-prevention test. Poult. Sci. 1955;34:1437-1440.

18. Bobek S, Jastrzebski M, Pietras M. Age-related changes in oxygen consumption and plasma thyroid hormone concentration in the young chicken. Gen. comp. Endocrinol. 1977;31:169-174.

19. Klandorf $H$, Sharp PJ, Newcomer WS. The influence of feeding patterns on daily variation in the concentrations of plasma thyroid hormones in the hen. IRC Med. Sci. 1981;9:82.

20. Davison TF. Circulating thyroid hormones in the chicken before and after hatching. Gen. comp. Endocrinol. 1975;29: 21-27. 21. Mehner A, Hartfiel W. Handbuch der Geflügelphysiologie. Volume 2. VEB Gustav Fisher Verlag. Jena. 1983. Germany, ISBN 3-8055-3738-7.

22. Statistical Analysis System (SAS, 2006, software version 9.1). SAS Users Guide, SAS Institute Cary, NC, USA.

23. Acar, N., Sizemore FG, Leach GR et al. Growth of broilers in response to feed restriction regimens to reduce ascites. Poult. Sci. 1995;74:833-843.

24. Gonzales E, Buyse J, Loddi MM et al. Performance, incidence of metabolic disturbances and endocrine variables of food restricted male broilers. Br. Poult. Sci. 1998;39:671-678.

25. Olawumi S. Effects of strain and feed restriction at starter phase on performance of broiler chickens in the humid tropics. International Journal of Agricultural Sciences and Natural Resources. 2015;2:1-5.
26. Decuypere E, Buyse J, Merat P, Zoons J, Vloeberghs J. Growth, abdominal fat content, heat production and plasma hormone levels of naked neck and control broiler chickens. Anim. Prod. 1993;57:483- 490.

27. Buyse J, Decuypere E, Huyghebaert G, Herremans M. The effect of clenbuterol supplementation on growth performance and onplasma hormone and metabolite levels of broilers. Poult. Sci. 1991;70:993-1002.

28. Kühn ER, Decuypere E, Colen LM, Michels H. Post-hatch growth and development of arhythmof thyroid hormones in chicks incubated at different temperatures. Poult. Sci. 1982;61:540-549.

29. Ucan-Marim, F,Arukwe A, Mortesen $A$ et al. Recombinant transthyretin purification and competitive binding with organohalogen compounds in two gull species (Larus argentatus and Larus hyperboreus). Toxicol Sci. 2009;107:440-450.

30. He J, Ohtsuka A, Hayashi K. Selenium influences growth via thyroid hormone status in broiler chickens. Br. J. Nutr. 2000;84:727-732.

31. Bogazzi F, Bartalena L, Brogioni S et al. L-thyroxine directly affects expression of thyroid hormone-sensitive genes: regulatory effect of RXRb. Mol. Cell Endocrinol. 1997;134:23-31.

32. Rahimi G. Thyroid hormones characteristic and hepatic deiodinase enzyme activity in broiler lines selected for growth and feed conversion. International Int. J. of Poultry Science. 2005:4:482-487.

33. Navidshad B, Shivarzad M, Zareshahneh A, Rahimi G. Effects of feed restriction and dietary fat saturation on performance and serum thyroid hormones of broiler chickens. Int. J. of Poultry Science. 2006;5:436-440.

\section{Source of Support: Nil.}

Conflict of Interest: None Declared.

Copyright: ( ) the author(s) and publisher. IJMRP is an official publication of Ibn Sina Academy of Medieval Medicine \& Sciences, registered in 2001 under Indian Trusts Act, 1882.

This is an open access article distributed under the terms of the Creative Commons Attribution Non-commercial License, which permits unrestricted non-commercial use, distribution, and reproduction in any medium, provided the original work is properly cited.

Cite this article as: Rabia M. Elwahesh, Khalid M. Ben-Elhaj, Marwan M. Draid. Relationship between Body Weight Performance and Plasma Thyroid Hormones in Broiler Hens. Int $\mathrm{J}$ Med Res Prof. 2016; 2(6):98-102.

DOI:10.21276/ijmrp.2016.2.6.019 